\title{
BLOOM (Irene), MARTIN (J. Paul), PROODFOOT (Wayne L.), Religious Diversity and Human Rights
}

New York, Columbia University Press, 1996, 355 p. (index)

Yves Lambert

\section{OpenEdition}

\section{Journals}

Édition électronique

URL : http://journals.openedition.org/assr/20859

DOI : $10.4000 /$ assr.20859

ISSN : $1777-5825$

Éditeur

Éditions de l'EHESS

Édition imprimée

Date de publication : 1 juin 2001

Pagination : 130

ISBN : 2-222-96704-X

ISSN : 0335-5985

\section{Référence électronique}

Yves Lambert, «BLOOM (Irene), MARTIN (J. Paul), PROODFOOT (Wayne L.), Religious Diversity and

Human Rights », Archives de sciences sociales des religions [En ligne], 114 I avril-juin 2001, document

114.59, mis en ligne le 19 août 2009, consulté le 21 septembre 2020. URL : http://

journals.openedition.org/assr/20859; DOI : https://doi.org/10.4000/assr.20859

Ce document a été généré automatiquement le 21 septembre 2020

(C) Archives de sciences sociales des religions 


\section{BLOOM (Irene), MARTIN (J. Paul), PROODFOOT (Wayne L.), Religious Diversity and Human Rights}

New York, Columbia University Press, 1996, 355 p. (index)

Yves Lambert

\section{RÉFÉRENCE}

BLOOM (Irene), MARTIN (J. Paul), PROODFOOT (Wayne L.), Religious Diversity and Human Rights, New York, Columbia University Press, 1996, 355 p. (index)

1 Cet ouvrage examine les relations entre les grandes religions et les Droits de l'homme. Une première partie fait opportunément le point sur le statut de l'individu et ses interprétations contemporaines dans le judaïsme, l'hindouisme, le bouddhisme, le christianisme et l'islam, montrant que chaque religion, même lorsqu'elle tend plutôt à subordonner l'individu à la communauté, présente de quoi fonder les droits de l'individu. La seconde partie traite de la genèse des notions de Droits de l'homme et de liberté religieuse. Elle souligne le fait que les vues de John Locke sur la loi naturelle, le contrat social et la tolérance, qui ont contribué au développement de ces notions, s'enracinent dans ses convictions religieuses; et le fait que l'idée d'une conscience personnelle inviolable peut trouver autant d'assises dans l'islam que dans le christianisme. Une dernière partie explore quatre exemples précis: le nationalisme hindou, le catholicisme en Amérique latine, le christianisme orthodoxe en Russie et la situation de la femme musulmane. La conclusion est que la diversité des religions ne conduit pas forcément au « conflit des civilisations » (cf. Samuel Huntington) car elle peut aussi se concilier avec l'existence d'une morale universelle liée aux Droits de l'homme. 